\title{
REFORMING OF THE PRIMARY EDUCATION SYSTEM IN UKRAINE (1917-1939)
}

\author{
Dolores Zavitrenko ${ }^{1}$, Natalia Berezenko ${ }^{2}$, Artem Zavitrenko ${ }^{3}$ \\ ${ }^{I}$ Ph.D. (Pedagogy), Associate Professor of the Special Education and Human Health Department, \\ Volodymyr Vynnychenko Central Ukrainian State Pedagogical University, Kropyvnitskyi, Ukraine, e-mail: \\ zavitrenkod@gmail.com,ORCID: https://orcid.org/0000-0002-2005-4810 \\ ${ }^{2}$ Graduate student of the Pedagogy and Management Department, Volodymyr Vynnychenko Central \\ Ukrainian State Pedagogical University, Kropyvnitskyi, Ukraine, e-mail: nberezenko29@gmail.com, \\ ORCID: https://orcid.org/0000-0003-3333-8924
}

${ }^{3}$ Teacher of English, Donetsk National Medical University, Kropyvnitskyi, Ukraine, e-mail: zavitrenkoartem@gmail.com,ORCID: https://orcid.org/0000-0002-1963-5343

Abstract. The article identifies positive trends of this period: state reform of the content of school education in connection with the stimulation of pedagogical and psychological research of scientific problems (differentiation and individualization of the educational process, stimulating cognitive activity of students, combining developmental and reproductive functions of education with preservation of material component). to increase the efficiency of the educational process, improve the conditions for the intellectual development of students and the quality of their general education); generalization of the system of didactic principles: the principle of the leading role of theoretical knowledge in primary education; the principle of learning at a high level of difficulty; the principle of fast pace of learning; the principle of students' awareness of the learning process. Based on the results of psychological and pedagogical research on the age cognitive abilities of children, the purpose and objectives of propaedeutics of primary education are specified.

The purpose of the study is to study, systematize, generalize and scientific coverage of archival, scientific, literary materials of a historical and pedagogical nature on the development and formation of education and pedagogical thought in Ukraine from 1917 to 1939.

It was found that the reforms of primary education in different historical periods were both an instrument of educational policy of governments and a catalyst for the development of pedagogical science for the modernization of school education. Summarizing the reasons for state reforms, we note that their selection and content were determined primarily by socio-political (change of governments, political regimes, creating conditions for the functioning of social order, interaction of the pedagogical community with government institutions), socio-economic (ensuring economic development educated, skilled workers) and only later pedagogical (state and needs of primary education in accordance with the needs of society, interaction with pedagogical science) determinants. The reform projects were based on advanced pedagogical principles, which outlined their directions, nature, results: equal access to education, compulsory and free education, democratic, national, unified school, connection of school with life, labor, social, educational, humanistic, pedocentric, scientific.

Thus, a significant part of primary education reforms was carried out in the following areas: change of structure (age of entry, terms, forms of education) and organization of the educational process (relationship between school and society, preparedness of teachers for reforms, assessment system); updating the content of education (theoretical aspects, the presence of the national component, the political component), methods and forms of education (verbal, active and creative).

Keywords: inclusion, inclusive education, child with special educational needs, socialization.

JEL Classification: I0; I20

Formulas: 0; fig.: 3; tabl.: 0; bibl.: 5

Introduction. The development of an independent Ukrainian state has created favorable conditions for the reconstruction and development of the national education system in Ukraine. There is a need to understand the historical facts, events and 
phenomena, to reflect in the content of historical education the laws of historical development, to reform the content of primary education, to fill it with cultural and historical heritage of the Ukrainian people.

Literature Review. Scientific researches, reflections in the works of L. Bondar, M. Gritsenko, P. Drobiazko, M. Lysenko, N. Pobirchenko, S. Sisoeva, O. Sukhomlinskaya, M. Stelmakhovich, B. Stuparyk, D. Fedorenko, A. Cherkashin, M. Yarmachenko, etc., reveal the problems of educational policy, general schooling, development of national education, ideas of the Ukrainian national school, originality and originality of the Ukrainian concept and models of general education, activities of teachers and public figures.

Aims. The purpose of this article is to analyze the formation and development of authentic pedagogical thought, Ukrainian schooling, reforming the system of primary education in Ukraine (1917-1939).

Results. The desire of the Ukrainian people to revive the national school, which emerged during the XIX and early XX centuries, was successful in the autumn of 1917. Ukrainian schools began to open in Ukraine. The General Secretariat of the People's Education, established by the Central Council, has joined the development of the educational business. He headed the General Secretariat and actively engaged in the development of the national education system I. Steshenko. May 20, 1917 The General Secretariat of Education has proclaimed the declaration outlining the program for the reorganization of public education. It stated that the secretariat was primarily intended to integrate the management of school education, namely: the care of conducting Ukrainian schools on the ground, organizing the publication of textbooks, teacher training. The merit of the secretariat was the fact that he took care of the elimination of the so-called dead-end schools, which were in tsarist public schools, and proclaimed the unity and continuity of all educational institutions from primary school to university [4].

Taking into account the support of the Central Rada, I. Steshenko is actively involved in holding the First All-Ukrainian Teachers 'Congress (April 5-6, 1917), where it was decided to establish an All-Ukrainian Teachers' Union. I. Steshenko became the organizer of the Second All-Ukrainian Teachers' Congress (August 1012, 1917), the All-Ukrainian Professional Congress (August 13-15, 1917) and the meeting on the organization of public education in Ukraine (December 15-20, 1917). on which the national education development plan was developed and approved [3].

November 7, 1917 there was a historic event. The Third Universal declared the creation of the Ukrainian People's Republic and the concentration in its hands of the full power [3].

Under the conditions of sovereign Ukraine, the development of a national school has risen to a new level. From the earliest days of the proclamation of the Ukrainian People's Republic, Ukrainian teaching was actively involved in the revival of the national system of education and upbringing. The UNR government gave priority to the issue of the revival and development of national education in Ukraine, which became a nation-state concern. 
December 28, 1917 The Central Council decides to reform the school case. UNR eliminates school districts where commissariats of all nationalities are created. This decision abolished the directorates and inspections of public schools. Instead, the institute of provincial and district commissioners of public education was established and school councils were attached to them [4].

The UNR government, given its national desire to create a home school, took care of providing (accessibility) education to all school-age children. The school was announced as a two-year comprehensive seven-year school. At the first stage of study time was determined for 4 years; on the second - 3 years. First of all, the first level of study was provided. Education at the UNR was proclaimed free, democratic in nature.

With the proclamation of the IV Universal of Ukraine's independence, the General Secretariat of Education becomes the Ministry of National Education of the UNR and continues the educational policy of its predecessor.

A significant contribution to the development of the national school was made by the Minister of National Education and Arts of the UPR in 1918-1919. prominent scientist I. Ogienko, later Minister of Religious Denominations (1919-1924). With his involvement and direct leadership, the "Petliur Unified School and Parent Committee Project in Ukraine" was developed. The main ideas and provisions of this project were reflected in the decisions of the Second Congress of the All-Ukrainian Teachers Union [4].

Discussion. A considerable amount of work was done by the Ministry of Education and the Arts, led by I. Ogienko, on the analysis and generalization of the state of education in Ukraine and on the design of the structure, content of a truly national education, and a national school.

The projects of the ministry and the government of the UNR, numerous ideas of educators about the construction of a new school essentially formed the concept of national education. It is based on the following guiding principles: the socio-state nature of education, when not only the state but also the parent community is recognized as the initiator of the national school; declared equal rights of all citizens to receive general education regardless of nationality, race, social origin and status, gender, religion; education of children in their mother tongue was introduced; Ukrainian language was compulsory for students of any nationality; envisaged diversity and differentiation of educational institutions; democratization of all aspects of school life, the election of school governing bodies, teachers and other school staff; it was planned to use the most appropriate curriculum and curriculum options, taking into account the interests and capabilities of students and parents; the highest governing body of the educational institution was to become a school council, which would be elected on a democratic basis; priority nature of financing and moral support of the school at the expense of education funds, which were formed from different sources of income (local budget, contributions of interested agencies, enterprises, cooperatives, societies, individuals, charitable organizations, revenues for paid services of the school); full financial and economic independence of the school and the national character of the educational activity of the school were guaranteed. 
The UNR government, the teaching of Ukraine did everything in their power to ensure that the provisions of the concept of national education and upbringing were not implemented in a declarative nature. In particular, the priority was to introduce free and compulsory education in lower and upper primary schools in Ukraine. In 1919, there were 50,244 elementary schools, 1,211 higher elementary schools in Ukraine [2].

State of Ukrainian elementary school in 1918-1939pp. was determined by the historical conditions in which Ukraine was between the two world wars. The situation of the Ukrainian school at that time was different, as Ukraine was in the conditions of fragmentation of lands under different governments: under the Bolsheviks, under Poland, under Romania, under Czechoslovakia. Because of the political circumstances of the time, the pedagogical events on these lands were almost completely separate and there were sporadic links between them. We consider the state of national education in the central Ukrainian territories.

Artificial borders separated the Ukrainian nation, Ukrainian schooling and pedagogy. Educational transformations in central Ukrainian lands began with the seizure of power by the Bolsheviks in December 1919. because of the destruction of conventional schools and the establishment of a unified Soviet school - the only labor.

The Bolshevik government in Ukrainian schooling largely duplicated the education system in Moscow. In 1919, a number of decrees were issued: the formation of the People's Commissariat of Education (People's Commissariat) of the USSR, provincial and district departments of public education; about the separation of the church from the state and the school from the church; about the transfer of all educational institutions under the control of the People's Commissariat, etc. Accordingly, the People's Commissar of the Ukrainian Soviet Socialist Republic issued a number of decrees and instructions on school management and the content of teaching, on the prohibition of teaching the Law of God and the exercise of religious education [5].

As of March 1920, the system of public education in Soviet Ukraine covered the following structures [4]:

- Preschool institutions (kindergartens and playgrounds) for children of 4 to 8 years;

- seven-year vocational school, which consisted of two grades for children of 8 to 15 years: first - 1-4 grades; second - 5-7 classes;

- vocational schools and colleges for teens and young people aged 15-18;

- Higher education institutions for young people of 18-22 years.

The above project of a unified labor school, created by the first People's Commissar of Education in Ukraine, G. Hrynko, in 1922 under the dictatorship of the Kremlin was changed and adapted to the system introduced in the RSFSR by A. Lunacharsky. In addition, in 1924 despite the autonomy in cultural construction, the People's Commissariat of Education in the USSR was forced to accept the Moscow program for a seven-year labor school [4].

Thus, despite its formal legal independence, the Ukrainian SSR was in fact subordinate to the Russian Federation (Moscow), which already in the 1920s 
intensively intervened in the affairs of Ukrainian schooling, and in 1930 took them under complete control and launched a powerful Russification. The study of the Russian language is introduced: not as a foreign language, but as a second language, ie equal to the native Ukrainian language.

Politics of military communism destroyed the economy, sputtered agriculture and hit the Ukrainian school system painfully.

In 1921-1923 pp. famine erupted in Soviet Ukraine, killing 1.5 million peasants. The economic collapse forced the Bolsheviks to move from the politics of military communism to the NEP, that is, to the free market, which promoted the development of private initiative. General liberalization opened the possibility to raise questions about the revival and development of Ukrainian pedagogical culture and the national school.

December 30, 1922 proclaimed the formation of the USSR. J. Stalin, who at that time was acting as a People's Commissar for Nationalities, led a large-scale Russification line, which caused intense dissatisfaction among non-Russians. Therefore, in April 1923, the XII Congress of the RCP (b) practically condemned Russian chauvinism and proclaimed the principle of rooting. The new national policy was to promote the training of Ukrainian teaching staff, the introduction of the mother tongue in education, the de-Russification of the state apparatus, and even the creation of a republican army. The process of Ukrainization began in Ukraine [3].

The Ukrainianization campaign covered all spheres of life in Soviet Ukraine. It had the greatest impact on education. Unlike tsarism, the Bolsheviks paid considerable attention to schooling. This was due to [4]:

a) for propaganda purposes;

b) the desire to raise the production potential of the country through education and vocational training;

c) the intention, through the Soviet school, pedagogy and education, to communicate to society.

Particularly impressive were the successes in eliminating illiteracy. In 1925. compulsory and free primary education was officially proclaimed, but no bourgeois and turmeric children were admitted to the school, so about half of the pupils were enrolled.

As for the successes in Ukrainianization, they were truly significant. The leading role in it was played by the People's Commissariat of Education, including its leaders O. Shumsky, and later M. Skrypnyk. Thanks to them, significant changes in Ukrainian national education and culture have been achieved. The culmination of the 1929 Ukrainianization. more than $80 \%$ of secondary schools and $30 \%$ of higher education institutions have provided exclusively Ukrainian language education 97\% of Ukrainian children have studied in their native language. In schools intensive study of Ukrainian studies was carried out, creative searches of effective ways of teaching of students were supported $[1,4]$.

Ukrainian studies encompassed a system of scientific knowledge and research on the history (genesis) of ethnicity, nature, language, nation, state, culture, 
international relations of Ukrainians with their own destiny and sovereignty, mentality and integrity (catholicity).

In May 1926. A. Shumsky was dismissed from his post of Education Commissar. And since September 1929 mass arrests and executions of prominent figures of Ukrainian science, education and culture began.

After the genocide against the Ukrainian peasantry, the offensive on Ukrainian national culture began (1933-1939pp.). By the tragic consequences, this time has come to be known as the "shot of revival". It was a period of curtailing of Ukrainianization and carrying out the Russification of all branches of Ukrainian life, education and pedagogy. The ethnocide, genocide and linguocide used by the Bolsheviks against the Ukrainians was accompanied by the physical extermination of the Ukrainian intellectual elite, nationally conscious teachers, which led to a mass beheading of the Ukrainian people. There was a defeat of the Ukrainian national school. All the best layers of Ukrainian national culture, science, literature and the arts, works by eminent Ukrainian and foreign writers were officially banned and were removed from school programs and textbooks. The school of the USSR did not even have its own textbooks, but used the ones published in the RSFSR.

Resolutions of the Central Committee of the CPSU (b) "On Primary and Secondary School" (1931), "On Curricula and Regime in Primary and Secondary School" (1932) meant the offensive on Ukrainian schooling and pedagogy, the introduction of a totalitarian regime, "enslavement" of teachers, ubiquitous planting of Stalin pseudopedagogy [2,3].

In the USSR, Soviet pedagogy advocated the formation of a Soviet man, not a Ukrainian. Teachers and scholars who stood in the national position of their native people were officially banned (G.Vashchenko, S.Rusov, Y.Chepiga, P.Kholodny, M.Demianovsky, P.Steblin, etc.). Official recognition was given only to those teachers who took to the Soviet platform (A. Makarenko, V. Zatonsky, Y. Ryapo, T. Lubenets, I. Sokoliansky, O. Zaduzhny, G. Kostyuk, S. Chavdarov, O. Popov) [ 2, 3, 4].

The constant waving of the sly brimstone of the struggle against "Ukrainian bourgeois nationalism" served as a screen of continuous persecution against all Ukrainian, national in school, education, pedagogical science. Love for the Fatherland, for the people, national patriotism, in the USSR was considered the most serious crime. From 1927 to 1939 up to 10 million people were destroyed in Ukraine.

The decision of the Central Committee of the CPSU (b) "On pedological distortions in the system of drug addicts" (1936) condemned the pedagogical theory of childlessness and infertility, falsification under quotations of communist "leaders" and "classics", the resolutions of party conferences, plenums and congresses [4]. . The number of Ukrainian-language schools in Soviet Ukraine has been sharply declining. Instead, they opened schools in Russian or bilingual (ultracurricular), which later became Russian. This insidious policy of the Bolshevik colonizers in the field of schooling has, over the decades, led to the decline of the national school and national consciousness. Stalinized politicization and militarization were waged in all the links of the school. 
Conclusion. Thus, the ukrainization of education brought back to life the national school of Ukraine, in which young people acquired the best achievements of the spiritual culture of their people. After centuries of persecution, humiliation in the Ukrainian people appeared national optimism. But the revival did not happen. The Ukrainian people opposed the Stalinist plans for socialist collectivization and industrialization. The leaders of the party and the state, led by J. Stalin, considered the reasons for the opposition to be the unconquered national spirit of Ukrainians, high level of national consciousness, their identity and their rejection of the Bolshevik ideology. The people were sentenced. The criminal collectivization of 1930-1931, the famine of 1932-1933, the mass extermination of the Ukrainian intelligentsia, and above all the figures of education, interrupted the process of ukrainization. Ukraine has completely lost the signs of autonomy and moved to the position of a suburban, colonial territory.

A frantic attack on the achievements of Ukrainian culture, education, and science began. The first in this process were actions aimed at liquidation of the national school of Ukraine, it was transformed into a means of genocide against Ukrainians, whose main task was to Russify the indigenous population, distort its national outlook, consciousness, character, excommunication from the traditions, customs and culture of its people.

Author contributions. The authors contributed equally.

Disclosure statement. The authors do not have any conflict of interest. References:

1. Avdienko M. (1928), Narodna osvita v Ukraini v

1927-1928rr [Public education in Ukraine in 19271928 ], Kiev: Radyanska osvita [in Ukrainian].

2. Bondar A. D (1968), Rozvutok syspilnogo vuhovannya v Ukrainskiy SSR 1917-1967 [ The Development of Public Education in the Ukrainian SSR 1917-1967], Kiev: Radyanska shkola [in Ukrainian].

3.Gritsenko M. S. (1966), Narusu z istorii shkolu v Ukrainskiy SSR 1917-1965 [Essays on the history of the school in the Ukrainian SSR 1917-1965], Kiev: Radyanska shkola [in Ukrainian].

4. Lyubar O. O., Stelmakhovich M. G., Fedorenko D. T. (2003), Istoriya ukrainskoi shkolu i pedagogiku: navchalnui posibnuk [ History of the Ukrainian school and pedagogy: textbook. Tool], Kiev: Znannya [in Ukrainian].

5. Medvid L. A (2003), Istoriya ukrainskoi shkolu i pedagogichnoi dymku v Ukraini [History of national education and pedagogical thought in Ukraine: Educ. Manual], Kiev: Vikar [in Ukrainian].

Received: November 15, 2020

Approved: December 03, 2020 